\title{
Stanowisko Seminarium Energetycznego Collegium Civitas w sprawie polityki energetycznej rządu RP 16 stycznia 2018 roku
}

The official position by the Energy Seminar of Collegium Civitas in a case of Energy Policy of Polish Government on 16 th January 2018

Seminarium Energetyczne Collegium Civitas działa od kwietnia 2015 roku. Łączymy akademickie aspiracje poznawcze z głębokq wiedzq praktyków gospodarki, ekspertów i menadżerów. Aktualnie w posiedzeniach uczestniczy około 40 uczestników reprezentujacych szkoły wyższe, firmy energetyczne oraz zespoły eksperckie.

W oparciu o referaty wygłoszone na Seminarium opublikowano 5 numerów interdyscyplinarnego czasopisma naukowego "Energetyka - Społeczeństwo - Polityka” (wersja internetowa: http://www.ejournals.eu/ESP/). 
Podczas posiedzenia Seminarium 25 listopada 2017 roku zostały przedyskutowane uwarunkowania ekonomiczne i technologiczne w zakresie wytwarzania i dystrybucji energii elektrycznej w Krajowym Systemie Energetycznym.

W opinii uczestników Seminarium istnieje pilna potrzeba przyjęcia przez Rząd dokumentu określającego strategię polskiej energetyki w perspektywie do roku 2050. Brak kierunkowych rozstrzygnięć $w$ tym obszarze powoduje poczucie niestabilności w zakresie bezpieczeństwa energetycznego państwa i może skutkować błędnymi decyzjami inwestorów lub brakiem decyzji.

Zdajemy sobie sprawę z faktu, że istnieje kilka dokumentów definiujących priorytety polityki energetycznej w Polsce, ale nie zostały one zaktualizowane.

Rząd Beaty Szydło nie zakończył dyskusji na temat celów strategicznych i nie przedstawił spójnej wizji rozwoju polskiej energetyki. Świadczy to o złożoności materii oraz o wadze decyzji, które wkrótce zostaną podjęte, dla całej polskiej gospodarki oraz dla indywidualnych konsumentów energii elektrycznej.

Toczą się też negocjacje rządu polskiego z instytucjami UE w kwestii dostosowania polskiej koncepcji finansowania inwestycji energetycznych do postanowień Pakietu Zimowego.

\section{W tym kontekście warto przedstawić podstawowe dylematy strategiczne polskiej energetyki, które należałoby rozstrzygnąć w ramach rządowej strategii:}

- Czy zasoby przemysłowe węgla kamiennego uzasadniają traktowanie go jako strategicznego źródła wytwarzania energii elektrycznej w perspektywie do roku 2050?

- Czy celowe jest wypełnienie wymogów polityki klimatycznej UE przez budowę elektrowni jądrowych, czy raczej przez budowę formie dużych farm wiatrowych na Bałtyku, wspomaganych przez lądowe farmy wiatrowe, instalacje fotowoltaiczne dużej mocy lub generację rozproszoną opartą na OZE i wspieraną gazem? 
- Czy dystans decydentów wobec koncepcji energetyki rozproszonej związany jest z ograniczeniami typu technologicznego i efektywnościowego tego podejścia, czy też wynika z centralistycznej wizji rozwoju polskiej energetyki?

- Jaka jest aktualna koncepcja, dotycząca wykorzystania dostaw gazu skroplonego (LNG) do wytwarzania ciepła i energii elektrycznej?

- Czy polskie koncerny energetyczne zmierzają do systemowego udziału w europejskim rynku energii, czy też dążą do pozycji autonomicznego gracza, na rynku krajowym i środkowoeuropejskim? W jakim stopniu określona strategia tych podmiotów uwzględnia aktualne regulacje wprowadzane przez UE?

- Jakie powinny być cele strategiczne polskiej energetyki w zakresie struktury miksu energetycznego do roku 2030 i w latach późniejszych?

\section{Zaprezentowane podczas obrad Seminarium Energetycznego referaty oraz przebieg dyskusji upoważniają do przedstawienia następujących rekomendacji:}

1. Krajowe zasoby przemysłowe węgla kamiennego są ograniczone. Dla powiększenia tych zasobów konieczne byłoby uruchamianie nowych obszarów eksploatacyjnych. Ze względu na strukturę i położenie tych zasobów, należałoby ponieść ponadstandardowe nakłady inwestycyjne, co w konsekwencji skutkowałoby bardzo wysokimi kosztami/cenami węgla. Polskie górnictwo aktualnie nie dysponuje odpowiednimi zasobami finansowymi, aby uruchomić realizację tego typu programów rozwojowych.

2. Sektor węglowy może mieć ciągle istotny wpływ na przyszłość energetyki pod warunkiem orientacji na skuteczną poprawę efektywności wydobycia oraz zastosowania nowych technologii przetwarzania węgla. Należy jednak mieć na uwadze kryterium ekonomicznej efektywności wdrożenia tych technologii.

3. Bankructwo takich potentatów jak amerykański Westinghouse Electric czy francuska Areva i rosnące opóźnienia w budowie bloków jądrowych w UE skłaniają do rozważenia ryzyka i ewentualnej rezygnacji z budowy elektrowni jądrowych. 
4. Konieczne jest podjęcie decyzji o modernizacji konwencjonalnych bloków energetycznych, których aktywność wytwórcza jest niezbędna dla zrównoważenia bilansu w szczytach energetycznych. Bloki te po modernizacji musiałyby spełniać normy ekologiczne UE.

5. Proces modernizacji konwencjonalnych bloków energetycznych nie powinien wpływać na ograniczanie rozwoju OZE, zarówno ze względu na nowe moce uruchamiane przez te źródła, jak też z uwagi na ich wpływ na ograniczenie średniej emisyjności sektora energetycznego.

Z upoważnienia uczestników

Koordynator Seminarium Energetycznego CC

dr hab. Paweł Ruszkowski, prof. Collegium Civitas 